\title{
Troponin: the biomarker of choice for the detection of cardiac injury
}

\author{
Luciano Babuin, Allan S. Jaffe
}

\section{ABstract}

It has been known for 50 years that transaminase activity increases in patients with acute myocardial infarction. With the development of creatine kinase (CK), biomarkers of cardiac injury began to take a major role in the diagnosis and management of patients with acute cardiovascular disease. In 2000 the European Society of Cardiology and the American College of Cardiology recognized the pivotal role of biomarkers and made elevations in their levels the "cornerstone" of diagnosis of acute myocardial infarction. At that time, they also acknowledged that cardiac troponin I and T had supplanted CK-MB as the analytes of choice for diagnosis. In this review, we discuss the science underlying the use of troponin biomarkers, how to interpret troponin values properly and how to apply these measurements to patients who present with possible cardiovascular disease.

CMAJ 2005;173(10):II9I-202

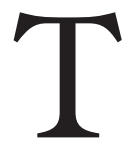

roponin is the biomarker of choice for the detection of cardiac injury. To use it properly, one must understand how sensitive the specific assay being used is for detecting cardiac injury, the fact that elevated troponin levels are highly specific for cardiac injury and some critical issues related to the basic science of the protein and its measurement. In this article, we review the biology of troponin, characteristics of assays that measure serum troponin levels and how to apply these measurements to patients who present with possible cardiovascular disease. We also discuss other clinical situations in which troponin levels may be elevated.

\section{The biology of troponin}

The 3-unit troponin complex (troponin I, T and C) along with tropomyosin is located on the actin filament and is essential for the calcium-mediated regulation of skeletal and cardiac muscle contraction. ${ }^{1}$ There are tissue-specific isoforms of troponin I, T and C..$^{2,3}$ Because the cardiac isoform of troponin C is shared by slow-twitch skeletal muscles, troponin C does not have cardiac specificity and thus is not used in assays for the diagnosis of cardiac injury. ${ }^{4}$

There is one cardiac troponin I (cTnI) isoform in myocardial tissue. ${ }^{5}$ This isoform has a post-translational tail of 32 amino acids on the $\mathrm{N}$-terminus. ${ }^{6,7} 7$ This sequence and the $42 \%$ and $45 \%$ dissimilarity with sequences of the other isoforms ${ }^{8}$ have made possible the generation of highly specific monoclonal antibodies without cross-reactivity with other noncardiac forms. ${ }^{9}$

Three genes control cardiac troponin $\mathrm{T}$ (cTnT). ${ }^{10}$ These genes and alternative mRNA splicing produce a series of isoforms ${ }^{10,11}$ with variable sequences close to the regions of the $\mathrm{N}$-terminus and C-terminus. ${ }^{10,12}$ Human cardiac muscle contains 4 troponin $\mathrm{T}$ isoforms, but only one is characteristic of the normal adult heart. ${ }^{13,14}$ Highly specific antibodies have been made to the $\mathrm{N}$-terminus-specific sequence of this cTnT isoform. ${ }^{15}$

The skeletal isoforms present in the fetal heart are replaced by cTnI and cTnT late during fetal development. ${ }^{16,17}$ cTnI is not expressed in skeletal muscle or other tissues during development ${ }^{17}$ or in response to degenerative or regenerative muscle disease processes. ${ }^{18}$ Thus, it is unlikely to be reexpressed in damaged tissues. The situation is more complex for cTnT. Re-expression of fetal forms occurs in cardiac tissue $^{12}$ and in diseased skeletal muscle. ${ }^{19}$ With the firstgeneration cTnT assay, this problem was compounded by a nonspecific tag antibody that cross-reacted with troponin $\mathrm{T}$ in skeletal muscle. ${ }^{20}$ Once this antibody was replaced by one with high specificity, false-positive elevations from skeletal muscle were eliminated. ${ }^{15}$ Studies using immunohistochemistry and polymerase chain reaction have confirmed that these fetal isoforms are not detected by the assay used today. ${ }^{21,22}$ Thus, the assay used to measure cTnT levels has cardiac specificity equivalent to that of assays for $\mathrm{cTnI}$.

\section{Characteristics of troponin assays}

Most troponin is found in the 3 -unit complex (troponin I, $\mathrm{T}$ and $\mathrm{C}$ ) of the contractile apparatus in myofibrils. There is also what has been termed a "cytosolic pool" of unbound troponin that is released acutely, 23,24 mimicking the appearance kinetics of other cytosolic proteins such as creatine kinase (CK). This pool represents about $6 \%$ of $\mathrm{cTnT}^{23}$ and $3 \%$ of cTnI, ${ }^{24}$ which is similar to the concentration of the CK-MB isoenzyme. ${ }^{24}$ The $13-15$-fold increased amount of troponin per gram of myocardium is mostly complexed, ${ }^{23,24}$ which explains the late but not early release of troponin. Thus, the increased overall amount of troponin in the heart is not why troponin is more sensitive than CK-MB. ${ }^{25,26}$ The increased early sensitivity likely reflects the fact that the percentage of 
Box 1: Critical values to know about troponin assays

- Lower limit of detection: The lowest level detectable that differs from zero. Assays with a lower limit of detection are more sensitive.

- Upper limit of normal: Usually defined as the 95th percentile (mean \pm 2 standard deviations) in a presumably normal "reference" population. For troponin, the European Society of Cardiology / American College of Cardiology task force recommended that the 99th percentile (mean \pm approximately 3 standard deviations) be used as the cut-off point, above which any value should be considered abnormal.

- Coefficient of variation (CV): A measure of how consistently an assay is able to produce the same result on the same sample. A CV of $10 \%$ is the level of precision suggested for troponin assays.

- Receiver operating characteristic (ROC) curve: The value at which the sensitivity of the troponin level is equivalent to that of the CK-MB level.

Note: $\mathrm{CK}-\mathrm{MB}=$ creatine kinase $\mathrm{MB}$ isoenzyme.

troponin released that reaches the blood after cardiac injury is greater for troponin than for CK-MB. ${ }^{27,28}$ Elevated troponin levels then persist in the blood owing to the slow release and degradation of the structural pool, ${ }^{23,29}$ since the half-life of troponin and its complex is about 2 hours. ${ }^{30}$ The prolonged window during which troponin levels are elevated allows for increased clinical detection of cardiac events and thus, functionally, greater clinical sensitivity.

With the first-generation troponin assays, about $33 \%$ of patients presenting with symptoms of acute coronary syndromes were found to have elevated troponin levels in the absence of elevated CK-MB levels. ${ }^{31}$ As assays have become more sensitive, an even greater number of patients have been identified with elevated troponin levels. Although the degree of improvement depends on the troponin assay used, the cut-off values adopted and the assay's sensitivity for CK-MB, the use of troponin rather than CK-MB has clearly increased the ability to detect myocardial damage secondary to ischemia perhaps as much as $130 \% .{ }^{32}$ However, there is huge variability in the sensitivity of assays, which is in no way reflected in the values reported for the various assays. The appropriate cut-off value for each assay is unique and cannot be compared with any other. ${ }^{33,34}$ These differences are due in part to the heterogeneity of the antibodies and matrix components of the assays. 9,35 They are also due to the fact that there are various fragments of troponin that circulate, and the antibodies used in the various assays detect these fragments differently. ${ }^{36}$

Troponin assays are not only more sensitive but are also more specific than CK-MB assays. Expression of CK-MB is not unique to the heart. ${ }^{37} \mathrm{CK}-\mathrm{MB}$ is found in skeletal muscle and the gastrointestinal tract as well as in the uterus of pregnant women. ${ }^{38}$ Moreover, in patients with myopathies, the CK-MB content of skeletal muscle can increase markedly to up to $50 \%$ of the total amount per gram of tissue. ${ }^{39}$ In addi- tion, CK-MB complexes with immunoglobulins can form. ${ }^{40,41}$ Thus, elevated CK-MB levels can occur because of analytical problems, macrocomplexes, trauma, rhabdomyolysis, myopathies or renal failure (owing to a myopathy), or during the peripartum period. ${ }^{42,43}$ The specificity of CK-MB can be enhanced by the calculation of the CK-MB/CK ratio. However, the use of this ratio markedly reduces sensitivity in patients with concurrent cardiac and skeletal muscle injury. ${ }^{44,45}$

For all intents and purposes, cTnI and cTnT provide comparable information, except in patients with renal failure (see "Troponin and renal failure").

The International Federation of Clinical Chemistry and Laboratory Medicine published quality specifications for cardiac troponin assays. ${ }^{36}$ The values that are used to characterize a troponin assay are presented in Box I. ${ }^{46}$ The wide range in the ability of various assays to detect low levels of troponin is highlighted by the range in the different cut-off values (the lower limit of detection, the 9gth percentile, the ro\% coefficient of variation and the receiver operating characteristic [ROC] curve) (Table I). This table may be used by clinicians to correlate troponin values obtained at hospitals using different assays from their own. The sensitivity of the different cut-off values in detecting acute myocardial infarction is illustrated in Fig. I.

\section{Role of troponin in acute myocardial infarction}

In 2000 a joint committee of the European Society of Cardiology and the American College of Cardiology (ESC/ACC) issued new criteria that acknowledged that elevations in biomarkers were fundamental to the diagnosis of acute myocardial infarction, 47,48 because symptoms may be atypical or nonexistent and electrocardiogram changes may be absent or nonspecific. ${ }^{49}$ By this time, cardiac troponin had supplanted MB-CK as the biomarker of choice for the detection of cardiac injury. ${ }^{50}$ The ESC/ACC criteria are included in Box 2.

To avoid false-positive results, the 99th percentile should be used as the cut-off value for diagnosing acute myocardial infarction. The use of 2 cut-off values ${ }^{51,52}-$ one to define infarction and a second designation for unstable angina with some degree of myocardial necrosis - has been suggested. ${ }^{51,52}$ The ESC/ACC joint committee felt that this approach lacked a scientific basis. ${ }^{50}$ Given the multiplicity of assays and the fact that different assays and laboratories advocate different cut-off values, the use of 2 cut-off values would have markedly increased the heterogeneity of diagnoses. In addition, with assays becoming more sensitive, the category of patients with unstable angina and myocardial necrosis would have increased in number. In addition, patients with elevated troponin levels have short- and long-term risk profiles, anatomy and pathophysiology similar to those of patients with conventionally diagnosed non-Q-wave myocardial infarction; therefore, singling this group out arbitrarily made little sense to the committee. ${ }^{50}$

The 99th percentile as a cut-off value can be applied con- 
sistently across assays even if the assays change. For some assays, but not others, there may be a need to alter the 99th percentile based on the patient's age, sex or race. ${ }^{53-55}$

The 99th percentile should be measurable with an imprecision (coefficient of variation) of I0\% or less. In July 2004 the first assay met these criteria. ${ }^{56} \mathrm{We}$ and others have advocated using the value at which there is I0\% coefficient of variation, to avoid analytical false-positive results. ${ }^{57}$

Like $\mathrm{CK}-\mathrm{MB}$, cardiac troponin concentrations begin to rise 4-6 hours after the onset of symptoms. Thus, a blood sample should be obtained on admission and again 6-9 hours later. Peak values occur at I8-24 hours after symptom onset. If it is difficult to ascertain the onset of symptoms, sampling should be based on the time of presentation. Values should be available within 60 minutes. ${ }^{47,48}$ Troponin elevations reflect myocardial damage but do not indicate its mechanism. In the absence of clinical evidence that the injury is due to coronary ischemia, other causes for cardiac damage should be sought.

If cardiac troponin assays are not available, the best alternative is $\mathrm{CK}-\mathrm{MB}$ measurement (preferably CK-MB mass). As with the troponin assays, the 99th percentile should also be used as the cut-off value. Measurement of analytes such as myoglobin and CK isoforms was suggested only if the test results would result in a change in therapy. With the improvement of troponin assays, it has become less clear that these analytes play any role ${ }^{58}$ (Fig. I). Previous studies that suggested they were of benefit were often based on high assay cut-off values or insensitive assays. ${ }^{59,60}$

\section{Prognostic value of troponin in acute coronary syndromes}

Prognosis and diagnosis are different, and thus troponin elevations may in some situations help to make a diagnosis but may not be prognostic. The reason for this may be that inadequate studies have been done or that the effect is too small to detect, if it exists at all. Nonetheless, in almost all series, even minor elevations in troponin levels presage short- and longterm events..$^{50}$ However, for patients with acute coronary syndromes and, increasingly, other entities such as heart failure and pulmonary embolism, diagnostic elevations of troponin invariably have prognostic and therapeutic significance. In patients with acute coronary syndromes, elevated levels of cTnI or cTnT are an adverse prognostic indicator (Fig. 2), even after adjustment for clinical predictors and electrocardiogram findings. ${ }^{61,62}$ These effects are short and long term. . $^{31,63}$

In patients with non-ST-segment elevation myocardial infarction (non-STEMI), angiographic data suggest that there are more acute and more complex plaques, more extensive disease, more thrombi and reduced Thrombolysis in Myocardial Infarction (TIMI) flow grades when troponin levels are elevated. ${ }^{64,65}$ The increased coagulation observed probably represents more severe disease rather than any other association. Since more severe disease may benefit from newer and more aggressive interventions, troponin elevations identify a group of patients who will benefit from therapy with delteparin and enoxaparin, studies of which showed a reduction in both mortality and recurrent

\begin{tabular}{|c|c|c|c|c|}
\hline Assay & LLD & $\begin{array}{c}\text { 99th } \\
\text { percentile }\end{array}$ & $10 \% \mathrm{CV}^{*}$ & $\begin{array}{l}\text { ROC } \\
\text { curve }\end{array}$ \\
\hline $\begin{array}{l}\text { ARCH STAT Troponin-I, Abbott } \\
\text { Diagnostics }\end{array}$ & 0.009 & 0.012 & 0.032 & 0.3 \\
\hline $\begin{array}{l}\text { AxSYM Troponin-I ADV, Abbott } \\
\text { Diagnostics }\end{array}$ & 0.02 & 0.04 & 0.16 & 0.4 \\
\hline i-STAT, $†$ Abbott Laboratories & 0.02 & 0.08 (WB) & 0.1 & ND \\
\hline Centaur, Bayer Diagnostics & 0.02 & 0.1 & 0.35 & 1.0 \\
\hline $\begin{array}{l}\text { Access AccuTnl Troponin I, Beckman } \\
\text { Coulter }\end{array}$ & 0.01 & 0.04 & 0.06 & 0.5 \\
\hline Triage Cardiac Panel, † Biosite & 0.19 & $<0.19$ & 0.5 & 0.4 \\
\hline Dimension RxL, Dade Behring & 0.04 & 0.07 & 0.14 & $0.6-1.5$ \\
\hline Stratus CS, $\uparrow$ Dade Behring & 0.03 & 0.07 & 0.06 & $06 .-1.5$ \\
\hline $\begin{array}{l}\text { Immulite, Diagnostic Products } \\
\text { Corporation }\end{array}$ & 0.1 & 0.2 & 0.6 & 1.0 \\
\hline Vitros, Ortho-Clinical Diagnostics & 0.02 & 0.08 & 0.12 & 0.4 \\
\hline Response, $\uparrow$ Ortho-Clinical Diagnostics & 0.03 & $<0.03$ (WB) & 0.21 & ND \\
\hline Elecsys, Roche Diagnostics & 0.01 & $<0.01$ & 0.03 & 0.1 \\
\hline Reader, $\uparrow$ Roche Diagnostics & 0.05 & $<0.05$ (WB) & ND & 0.1 \\
\hline $\begin{array}{l}\text { Tosoh AIA, Global Medical } \\
\text { Instrumentation Inc. }\end{array}$ & 0.06 & $<0.06$ & 0.06 & $0.31-0.64$ \\
\hline
\end{tabular}


myocardial infarction; ${ }^{66,67}$ no benefit was observed among patients without elevated troponin levels. A large number of trials, including at least 3 randomized trials, ${ }^{68-70}$ have investigated the use of glycoprotein IIb/IIIa platelet inhibitors and have shown that troponin elevations identify a group in which a more aggressive antiplatelet aggregation therapy is useful. Subsequent nonrandomized ${ }^{71}$ and randomized studies ${ }^{72,73}$ have confirmed that early coronary intervention also attenuates the adverse prognostic impact of troponin elevations. ${ }^{74,75}$ Of the agents used to treat acute coronary syndromes, only clopidogrel seems to benefit patients with and without troponin elevations. ${ }^{76} \mathrm{Al}-$ though there are no direct data, this is likely also true for ASA.

Elevated troponin levels on admission are also of value for patients with ST-segment elevation myocardial infarction (STEMI). Regardless of therapy, an elevated troponin level is an independent predictor of death at 30 days and during long-term follow-up. ${ }^{77,78}$ This is because elevations predict incomplete epicardial and more severely impaired myocardial perfusion despite normal epicardial flow. ${ }^{79}$ Some of this effect may be attenuated by stenting.

With both STEMI and non-STEMI, there is relation between the extent of the increase in troponin levels and adverse events. ${ }^{61,77}$ The prognostic value of cTnT and of cTnI appear equivalent. ${ }^{80,81}$

\section{Can troponin detect reversible cardiac injury?}

The question of whether biomarkers in general, or troponin in particular, are released after reversible or irreversible injury has been debated for years. ${ }^{82}$ In animal experiments, increased CK activity in blood has been associated with evi-

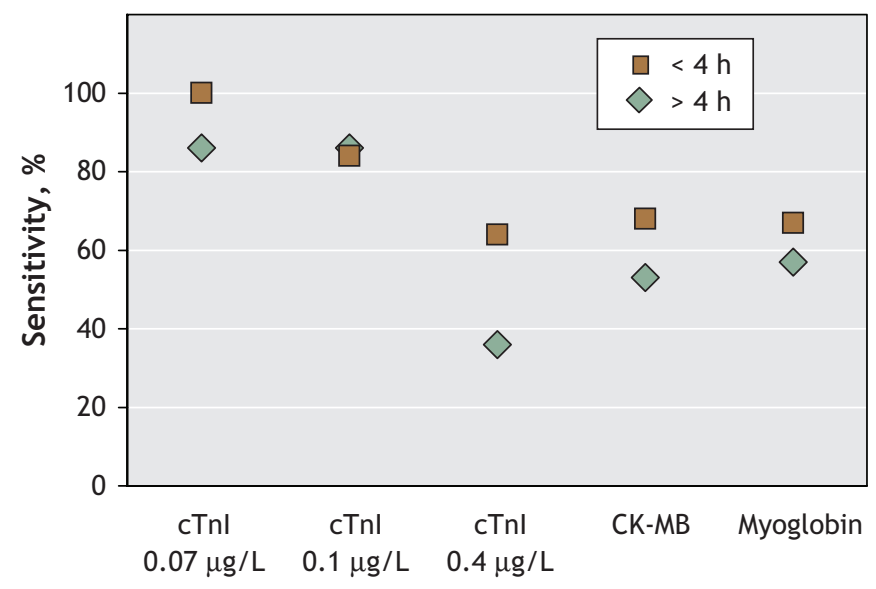

Fig. 1: Sensitivity of different cut-off values of cardiac troponin I (cTnl) over time; $0.07 \mathrm{mg} / \mathrm{L}=99$ th percentile, $0.1 \mathrm{mg} / \mathrm{L}=10 \%$ coefficient of variation, $0.4 \mathrm{mg} / \mathrm{L}=$ receiver operating characteristic (ROC) curve. Reprinted, with permission, from Eggers KM, Oldgren J, Nordenskjold A, et al. Diagnostic value of serial measurement of cardiac markers in patients with chest pain: limited value of adding myoglobin to troponin I for exclusion of myocardial infarction. Am Heart J 2004;148:574-81.
Box 2: $1999 \mathrm{ESC} / \mathrm{ACC}$ criteria for the diagnosis of acute, evolving or recent myocardial infarction (MI)

Either one of the following criteria satisfies the diagnosis of acute, evolving or recent $\mathrm{Ml}$ :

- Typical rise and gradual fall (troponin) or more rapid rise and fall (CK-MB) of biochemical markers of myocardial necrosis with at least one of the following:

- Ischemic symptoms

- Development of pathological Q waves on ECG

- ECG changes indicative of ischemia (ST-segment elevation or depression)

- Coronary artery intervention (e.g., coronary angioplasty)

- Pathological findings of acute MI

Note: ESC/ACC = European Society of Cardiology / American College of Cardiology, CK-MB = creatine kinase MB isoenzyme, ECG = electrocardiogram. Source: Eur Heart J 2000;21:1502-13, ${ }^{47}$ and J Am Coll Cardiol 2000;36:959-69. ${ }^{48}$

dence of irreversible cardiac injury (cell disruption). ${ }^{83}$ Troponin elevations have not been detected in humans who experienced reversible ischemia after exercise stress testing. ${ }^{84}$

The molecular weights of cTnI and cTnT are 23500 and 33500 Daltons respectively. However, even if free troponin chains are smaller than CK-MB (86 ooo Daltons), much of the troponin is released as a complex with a higher molecular weight. ${ }^{85,86}$ Some have argued that the transient troponin release in experimental models of vital exhaustion, ${ }^{87}$ experimental studies with longer ischemia times ${ }^{88}$ and in some exercise studies ${ }^{89,90}$ may be due to the release of troponin from the "cytosolic pool" only. This also has been observed in patients with pulmonary embolism ${ }^{91,92}$ and sepsis. ${ }^{93}$ The failure of continuing release has been attributed to the lack of release of structurally bound troponin and thus "reversible injury." ${ }_{11,92}$ Such speculation fits with the known difficulty of causing right ventricular infarction ${ }^{94}$ and with the recovery of left ventricular function in patients with septic shock.95,96

Since one cannot distinguish one type of release from the other, and given that the situation for troponin is likely the same for all biomarkers, it is unclear how important this issue is clinically. ${ }^{50}$

\section{Chest pain in the emergency department}

Patients who present with chest pain, in whom unstable coronary disease is possible but not overt, are at higher risk of cardiac events if troponin is elevated. In a landmark study, Hamm and colleagues ${ }^{97}$ evaluated the effectiveness of rapid triage using bedside tests to detect cTnI and cTnT in 733 patients with acute chest pain in an emergency department as long as one sample was obtained at least 6 hours after the onset of symptoms. Patients with normal troponin values had a negligible incidence of events over a 30-day follow-up. ${ }^{97}$ The assays used in that study were less sensitive than contemporary assays. In another study involving patients who presented with chest 
pain but who had normal ECGs, coronary artery disease was found in $90 \%$ of those with an elevated troponin level and in $23 \%$ of those with a normal troponin level $(p<0.001) .{ }^{98} \mathrm{Had}$ the 9gth percentile been used instead of the much higher ROC cut-off value for the troponin levels, even more patients with coronary artery disease would likely have been identified.

When using low cut-off values for patients with a low pretest probability of disease, it is important to understand that analytical false-positive results may occur owing to imprecision of the assays at low levels. ${ }^{46}$

\section{Troponin and the detection of myocardial reinfarction}

Reinfarction is difficult to detect with any biomarker while values are rising or falling. Troponin is no different. However, a recent study ${ }^{99}$ compared the patterns of increases in cTnI and $\mathrm{CK}-\mathrm{MB}$ levels in 3 patients with acute myocardial infarction who had a reinfarction in hospital. In each case, substantial reelevations in cTnI levels occurred (Fig. 3). These findings are similar to previous data, ${ }^{100,101}$ which suggests that changes in troponin levels are adequate to diagnose reinfarction and that $\mathrm{CK}-\mathrm{MB}$ measurement is not needed in this situation.

\section{Troponin and infarct size}

Infarct size can be estimated from the troponin value measured at 72 hours. The data are stronger for this approach with cTnT than with $c T n I,{ }^{102,103}$ which suggest that the cTnT level measured at 72 hours is a good estimate of scintigraphic infarct size whether patients were reperfused or not. ${ }^{103}$ For cTnI, peak levels work better, ${ }^{28,104}$ but the data vary depending on whether or not there has been acute reperfusion. ${ }^{104}$ The estimates of infarct size are superior to those provided by CK or CK-MB.

\section{Troponin after percutaneous coronary interventions}

After percutaneous coronary interventions (PCIs), increases in troponin levels above the 9gth percentile are indicative of cardiac cell injury and thus fulfill the definition of acute myocardial infarction. ${ }^{47,48}$ This may be a situation in which diagnosis and prognosis are different. Thus, the ESC/ACC group recommended that these cases of acute myocardial infarction be considered separately from spontaneous infarctions, that they be reported separately in clinical trials and that they have different reimbursement codes. ${ }^{47,48}$

The mechanisms by which PCIs cause cardiac damage are poorly defined despite the adverse consequences. ${ }^{105,106}$ Thus, whether minor troponin elevations have similar prognostic influence is unclear. It may depend on the cause of the elevation. Some degree of cardiac injury may be necessary to accomplish an adequate procedure, and in that situation a minor amount of cardiac injury may not be adverse. ${ }^{107,108}$ In other cases, elevated troponin levels may reflect more severe or diffuse disease.
Several considerations are important in regard to elevated troponin levels after PCI.

- Patients with acute coronary syndromes may have elevated troponin levels at baseline that increase owing to the continuing release of troponin rather than the release after PCI-related cardiac injury. It is known that elevated levels at baseline have prognostic importance. ${ }^{77,79}$ Some have suggested that increases of more than $25 \%$ should be considered due to the procedure, ${ }^{58}$ but such increases could still be part of the initial insult with rising troponin values. This may be a group of patients in which post-PCI infarction cannot be diagnosed in the absence of clear-cut complications. A baseline troponin level is essential for the proper interpretation of post-PCI elevations. ${ }^{109,110}$

- Troponin measurement every 6-8 hours for 24 hours is ideal. ${ }^{111}$

- Only one troponin assay should be used given the heterogeneity of assays. This is particularly important for multicentre trials.

- Values above the 99th percentile should be used to define elevations.

- Long-term follow-up (2-3 years) may well be helpful to define the prognostic effects of elevations. ${ }^{112}$

None of the studies present in the literature has dealt with all of these issues. The same criteria should be used to investigate the relation between specific therapies (e.g., statins ${ }^{113}$ ) and the prevention of myocardial damage after PCI.

\section{Troponin after cardiac surgery}

Factors related to cardiac surgery that contribute to myocardial damage include the duration of cross clamping and cardiopulmonary bypass; potential occlusion of a graft; the nature, temperature and adequacy of the cardioplegia; the use of cardiopulmonary bypass itself (owing to activation of

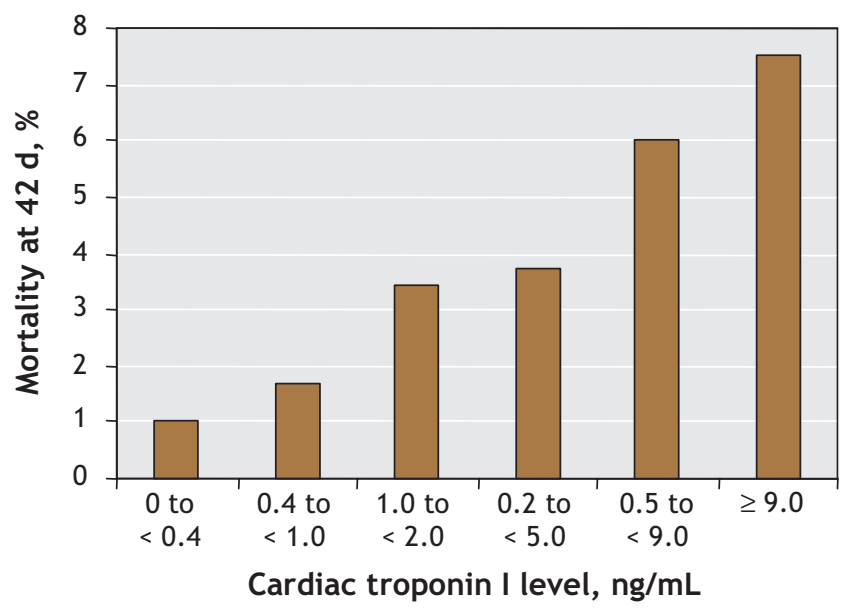

Fig. 2: Morality rates according to level of cardiac troponin I at baseline. Reprinted, with permission, from Antman EM, Tanasijevic MJ, Thompson B, et al. Cardiac-specific troponin I levels to predict the risk of mortality in patients with acute coronary syndromes. N Engl J Med 1996;335:1342-9. Copyright (c) 1996 Massachusetts Medical Society. All rights reserved. 

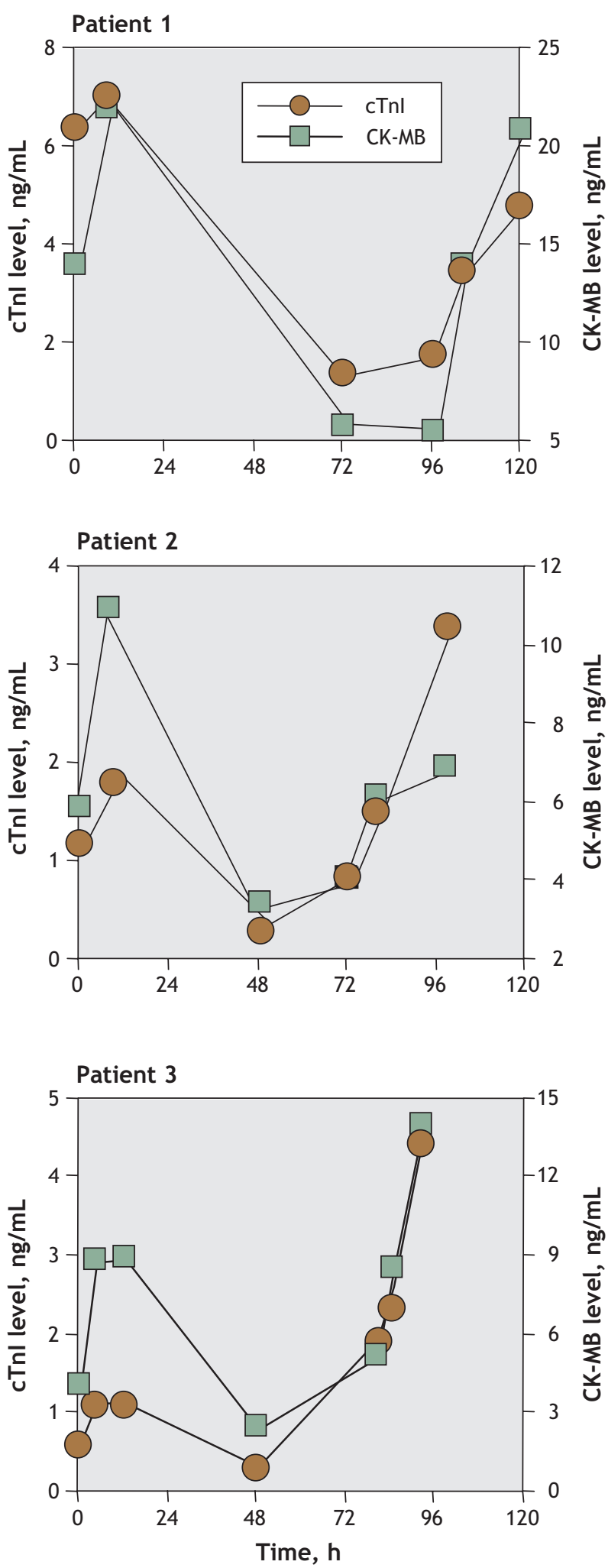

Fig. 3: Cardiac troponin I and CK-MB levels in patients with acute myocardial infarction who experienced a reinfarction in hospital. Reprinted, with permission, from Apple FS, Murakami MM. Cardiac troponin and creatine kinase $M B$ monitoring during inhospital myocardial reinfarction. Clin Chem 2005;51(2):460-3. platelets, complement and cytokines); direct trauma to the heart; coronary artery or venous graft embolism; and other complications of the procedure. ${ }^{114}$

Some damage is unavoidable. The relevant clinical issue is to define whether the degree of myocardial damage is "clinically significant." ${ }_{114}$ Biomarkers cannot determine the mechanism of injury. ${ }^{57}$ However, irrespective of the mechanism, the higher the value after surgery, the greater the damage ${ }^{115,116}$ and the worse the prognosis. ${ }^{17,118}$ Some have suggested that late-peaking elevations are indicative of graft occlusion, ${ }^{119}$ but proof of this concept is unavailable. Eventually, the ability to monitor cardiac biomarkers should be a useful way to improve strategies for myocardial protection ${ }^{120,121}$ and surgical approaches. ${ }^{122,123}$

\section{Troponin and renal failure}

Troponin is the biomarker of choice for detecting cardiac injury in patients with renal failure, including those with endstage renal disease (ESRD) receiving long-term dialysis. ${ }^{124,125}$ Among 7033 patients with suspected coronary syndromes enrolled in the Global Use of Strategies to Open Occluded Coronary Arteries IV (GUSTO-IV) trial for whom complete baseline data on cTnT levels and creatinine clearance rates were available, elevated TnT levels were found to predict shortterm prognosis regardless of creatinine clearance. ${ }^{126}$ This correlation is probably also true for cTnI.

However, the concept that increases could be "artifactual" 109,110 remains, because asymptomatic ESRD patients are more apt to have elevated levels of cTnT than of cTnI despite the fact that the newer $\mathrm{cTnT}$ assays do not detect cross-reacting isoforms from skeletal muscle. ${ }^{15,21}$ Numerous studies have confirmed the importance of cardiovascular diseases in ESRD patients. ${ }^{127,128}$ Atherosclerotic risk factors such as diabetes, ${ }^{129,130}$ hypercholesterolemia, ${ }^{131,132}$ left ventricular hypertrophy ${ }^{133,134}$ and severe coronary artery calcification ${ }^{135}$ are associated with increases in cTnT levels in hemodialysis patients, which supports the concept that elevations are secondary to myocardial injury. ${ }^{136,137}$ In a study by Ooi and colleagues, ${ }^{138}$ minor elevations in troponin levels were invariably associated with pathological evidence of myocardial damage in patients with and without renal failure. Furthermore, prognostic studies have confirmed that such elevations are indicators of future cardiac events. Apple and colleagues ${ }^{139}$ evaluated survival among 773 ESRD patients. Those with elevated cTnT levels (defined by the 99th percentile cut-off value) had an increased risk of death after I, 2 and 3 years of follow-up. Increases in cTnT and cTnI levels in ESRD patients showed a 2- to 5-fold increase in mortality, with greater numbers of patients having an increased $\mathrm{cTnT}$. These data have been confirmed in subsequent studies. Some have suggested that C-reactive protein elevations augment the prognostic significance of troponin elevations in this setting. ${ }^{140,141}$

Most studies have shown that only minor changes in troponin levels occur with dialysis. There are differences between $\mathrm{cTnI}$ and $\mathrm{cTnI}$ concentrations before and after dialysis: cTnI decreases or does not change, whereas cTnT concentrations increase after dialysis, albeit minimally. CK-MB can also 
be elevated in these patients in the absence of cardiac disease and its measurement is not helpful in these patients. ${ }^{109}$

The critical clinical question is how to distinguish between troponin elevations that are due to acute coronary syndromes and those that are due to more chronic conditions. One way is to obtain a baseline value for comparison. The FDA has approved cTnT measurement for risk stratification and for this purpose. One can also use changing values to define acute episodes. If there are dynamic changes, acute disease is likely present. In the absence of a changing pattern, one may need to address the more chronic problem rather than treat emergently.

There is no definitive information about the diagnostic etiologies or the therapeutic and preventive strategies appropriate for dialysis patients with elevated troponin levels. ${ }^{142}$ These elevations could reflect silent myocardial necrosis, ${ }^{127}$ especially in patients with a history of ischemic heart disease; ${ }^{132,136}$ left ventricular hypertrophy associated with perfusion defects or abnormal coronary vasomotion;:136,143 left ventricular systolic dysfunction; ${ }^{134}$ increased cardiac preload with myocardial stretch; ${ }^{129,144}$ microvascular disease, especially in diabetic patients; ${ }^{127,129}$ endothelial dysfunction secondary to oxidative stress and inflammation; ${ }^{145,146}$ episodes of hypotension during dialysis; ${ }^{147}$ or cardiac injury secondary to calcium and oxalate deposition. ${ }^{148}$ Troponin elevations are unlikely owing to delayed clearance of troponin despite recent claims. ${ }^{149}$

\section{Other clinical situations in which troponin levels may be elevated}

The increased sensitivity and specificity of troponin assays now make it clear how often some degree of cardiac damage occurs. In critically ill patients, such elevations have profound prognostic importance. ${ }^{150,151}$ Elevations can be due to occult coronary artery or toxic substances such as tumour necrosis factor and heat-shock protein, as occurs in sepsis. ${ }^{93}$ Elevations can also be due to either acute or more chronic processes (Box 3).

Direct damage could be secondary to physical energy of different types: mechanical (i.e., contusion, as in cardiac trauma or cardiac surgery) or electrical (e.g., cardioversion, ablation or implantable cardioverter defibrillator [ICD] firings).

- Cardiac trauma: Blunt cardiac trauma ("cardiac contusion") includes a broad spectrum of nonpenetrating trauma to the chest. CK-MB elevations are common and can come from injury to skeletal muscle. Troponin elevations are highly specific and usually indicate cardiac trauma.45,152 Elevations are usually modest; more extreme elevations may be due to concomitant coronary artery disease or coronary trauma. It is unclear whether troponin elevations can be used to predict complications or guide therapy. ${ }^{153,154}$

- Cardioversion, ablation and cardiac arrest: Elective electrical cardioversion in most patients does not result in troponin elevations. ${ }^{155,156}$ When present, elevations are mild. ${ }^{157,158}$ Elevations are more common in patients with cardiac arrest who have undergone direct-current shock (often multiple) or prolonged resuscitation, or both. ${ }^{159,160}$
Box 3: Conditions in which troponin levels may be elevated without overt ischemic heart disease

- Trauma (e.g., contusion, ablation, pacing, ICD firings, cardioversion, endomyocardial biopsy, cardiac surgery)

- Congestive heart failure, acute and chronic

- Aortic valve disease and hypertrophic obstructive cardiomyopathy with significant left ventricular hypertrophy

- Hypertension

- Hypotension, often with arrhythmias

- Noncardiac surgery without complications

- Renal failure

- Severe asthma

- Critical illness, especially diabetes, respiratory failure, hemolytic uremic syndrome

- Drug toxicity (e.g., adriamycin, 5-fluorouracil, herceptin, snake venoms)

- Hypothyroidism

- Coronary vasospasm, including apical ballooning syndrome

- Inflammatory disease (e.g., myocarditis, parvovirus B19 infection, Kawasaki disease, myocardial extension of bacterial endocarditis)

- Percutaneous coronary intervention without complications

- Pulmonary embolism, severe pulmonary hypertension

- Sepsis

- Burns, especially if total body surface area affected is $>30 \%$

- Infiltrative diseases, including amyloidosis, hemochromatosis, sarcoidosis and scleroderma

- Acute neurologic diseases, including cerebrovascular accident and subarachnoid bleed

- Rhabdomyolysis with cardiac injury

- Transplant-related vasculopathy

- Vital exhaustion

Note: ICD = implantable cardioverter defibrillator.

Substantial elevations should suggest the presence of myocardial injury from causes (ischemic or not ischemic) unrelated to resuscitation. ${ }^{157}$ Elevations after ablations are related to the amount of energy used but are usually modest. ${ }^{161,162}$ This is also the case for ICD firings and endomyocardial biopsies.

There also could be a variety of toxic insults that may exacerbate underlying ischemic heart disease or could function to damage the heart directly.

- Sepsis: Troponin elevations in patients with sepsis are common. ${ }^{163,164}$ The mechanism in any given patient is unclear. Elevations could be due to underlying coronary artery disease, hypotension, septic microemboli, high doses of vasoactive drugs, or the effects of cytokines such as heatshock protein and tumour necrosis factor- $\alpha .{ }^{165}$ Clinically, elevations occur more frequently in patients with more severe left ventricular systolic dysfunction ${ }^{163,164}$ and higher 
critical illness scores. ${ }^{164,160}$ Most studies found a relation between increased troponin levels and mortality. 167,168

- Chemotherapy: Cardiotoxicity is a common complication of high-dose chemotherapy. Troponin elevations, soon after chemotherapy and in the short-term follow-up period, are associated with left ventricular dysfunction and cardiac events. ${ }^{169}$

- Other toxins: Snake venom and other agents (e.g., catecholamines) either ingested, infused or released systemically can cause troponin elevations.

- Cardiac rhabdomyolysis: Increases in troponin levels can identify cardiac involvement with rhabdomyolysis. ${ }^{170}$ Such elevations are associated with an adverse prognosis. ${ }^{171}$

Damage could be secondary to inflammation (i.e., myocarditis or acute rejection) or an infiltrative process that involves the myocardium (i.e., pericarditis).

- Myocarditis: Lymphocytic infiltration of the heart, be it focal or diffuse, can easily explain troponin elevations. ${ }^{172}$ Acutely, myocarditis can mimic acute myocardial infarction. Chronically, elevations are time-dependent ${ }^{173,174}$ and generally occur early after the onset of symptoms. Myocarditis might also be the reason for troponin elevations after vaccination in some patients, and after systemic inflammatory illnesses such as Kawasaki disease.

- Pericarditis: In acute pericarditis, troponin elevations are common, especially when ST-segment elevation is present. ${ }^{175,176}$ Troponin release probably represents inflammatory involvement of the epicardium. ${ }^{176}$

- Amyloidosis: Troponin elevations occur often in patients with amyloid infiltration of the myocardium ${ }^{177}$ and likely in patients with other infiltrative myopathies as well. The extent of cardiac involvement in patients with primary systemic amyloidosis is the most important predictor of clinical outcome. ${ }^{178}$ Troponin can be measured along with NTproBNP (N-terminal pro-brain natriuretic peptide) and other clinical variables for risk stratification. ${ }^{179,180}$

Cardiac damage can be ischemic but not be due to overt epicardial coronary artery disease. For example, with left or right ventricular hypertrophy, there is often increased wall stress and a relative imbalance between oxygen supply and demand. This could be the cause of troponin elevations in patients with and without concomitant coronary artery disease who have hypertrophic obstructive cardiomyopathy, aortic stenosis, acute pulmonary embolism, chronic pulmonary hypertension and congestive heart failure. In addition, acute myocardial stretch from increased cardiac preload can result in proteolysis of troponin and cause its release. ${ }^{181}$ This likely is part of the mechanism for troponin elevations in patients with renal disease and those with acute congestive heart failure and perhaps pulmonary embolism.

- Pulmonary embolism: Acute right ventricular strain secondary to increases in pulmonary arterial resistance is the cause of troponin elevations in pulmonary embolism. ${ }^{182}$ Elevations usually resolve in 40 hours or less. Pulmonary embolism can cause right ventricular infarction. ${ }^{183,184} \mathrm{Hy}-$ potension, hypertension and tachycardia could contribute with or without concomitant coronary artery disease. Troponin elevations are more likely to occur in patients with shock ${ }^{185,186}$ and clinical variables ${ }^{187,188}$ associated with poor outcome. One might be able to measure troponin levels to determine which patients need more aggressive therapy. ${ }^{187,189}$ Troponin elevations in pulmonary hypertension, likely due to a pathophysiology similar to that in pulmonary embolism, also have prognostic importance. ${ }^{190}$

- Heart failure: Elevations in cTnI and cTnT levels occur in patients with heart failure, in both the acute decompensated ${ }^{191,192}$ phase and the stable phase. ${ }^{193,194}$ Elevations are not solely due to coronary artery disease; patients with cardiomyopathy have elevations as well. These elevations have strong prognostic importance.

- Subendocardial ischemia: There is an association between increased troponin levels and left ventricular hypertrophy. ${ }^{195}$ It is known that the subendocardium can have impaired perfusion due to increased wall stress, concomitant endothelial dysfunction and, often, increased myocardial oxygen demand. This is the mechanism for ischemia in patients with aortic stenosis, hypertrophic obstructive cardiomyopathy, and probably severe hypotension or hypertension with left ventricular hypertrophy. Catecholamines, which are released with stress and neurological insults, may also cause cardiac injury in this manner.

- Endothelial dysfunction: Recent data are clear that ischemia can be induced by endothelial abnormalities. ${ }^{196}$ These can lead to cardiac injury and troponin release.

\section{Key points for clinical practice}

- Cardiac isoforms of troponin are specific for the heart.

- Elevated troponin levels indicate cardiac injury but do not define the mechanism.

- In patients with acute coronary ischemia and elevated troponin levels, myocardial infarction should be diagnosed; treatment should be guided by the elevated troponin levels.

- In patients who do not have acute coronary ischemia, rule out other causes of troponin elevation.

- Patients with renal failure and elevated troponin levels should be evaluated initially for acute coronary syndromes. In the absence of an acute cause of the elevation, emergent treatment may not be required. If no urgent care is needed, subsequent troponin measurement is still indicated, since troponin elevations have prognostic importance.

- Know the 99th percentile of the troponin assay used.

- Elevated troponin levels imply an adverse prognosis. In some patients (e.g., those with acute coronary syndromes) troponin elevations may be short term and long term, and in other patients (e.g., dialysis patients and those having undergone vascular surgery) they may only be long term.

- Suspect a laboratory problem if the troponin values do not change or do not match the patient's presentation. Good laboratories can help to determine whether there are analytical issues confounding the results. The first approach is to repeat the assay after additional centrifugation to be sure to eliminate fibrin interference. Kits are available to correct for the presence of heterophilic and cross-reacting antibodies. ${ }^{197}$ 
This article has been peer reviewed.

From the Cardiovascular Division and Division of Laboratory Medicine, Mayo Clinic and Mayo Clinic Graduate Medical School, Rochester, Minn.

Competing interests: None declared for Luciano Babuin. Allan Jaffe is a consultant to and receives research support from Roche, Dade Behring and Beckman Coulter; he has been or currently is a consultant to Ortho Diagnostics, Sensera, diaDexus, Abbott, Hawaii Biotech, Pfizer and Tartagen.

Contributors: Both of the authors contributed to the drafting and critical revision of the manuscript, gathered the information presented and approved the final version for publication.

\section{REFERENCES}

I. Takeda S, Yamashita A, Maeda K, et al. Structure of the core domain of human cardiac troponin in the $\mathrm{Ca}(2+)$-saturated form. Nature 2003;424:35-4I.

2. Dhoot GK, Gell PG, Perry SV. The localization of the different forms of troponin I in skeletal and cardiac muscle cells. Exp Cell Res i978;117:357-70.

3. Dhoot GK, Perry SV. Distribution of polymorphic forms of troponin components and tropomyosin in skeletal muscle. Nature 1979;278:714-8.

4. Schreier T, Kedes L, Gahlmann R. Cloning, structural analysis, and expression of the human slow twitch skeletal muscle/cardiac troponin $\mathrm{C}$ gene. J Biol Chem I990;265:21247-53.

5. Cummins P, Perry SV. Troponin I from human skeletal and cardiac muscles. Biochem J I978; I71:25I-9.

6. Vallins WJ, Brand NJ, Dabhade N, et al. Molecular cloning of human cardiac troponin I using polymerase chain reaction. FEBS Lett I990;270:57-6I.

7. Perry SV. Troponin I: inhibitor or facilitator. Mol Cell Biochem 1999;190:9-32.

8. Katrukha A. Antibody selection strategies in cardiac troponin assay. In: Wu AHB editor. Cardiac markers. 2nd ed. Totowa (NJ): Humana Press Inc., 2003. p. 173-85

9. Larue C, Defacque-Lacquement $\mathrm{H}$, Calzolari C, et al. New monoclonal antibodies as probes for human cardiac troponin I: epitopic analysis with synthetic peptides. Mol Immunol 1992;29:27I-8.

Io. Perry SV. Troponin T: genetics, properties and function. J Muscle Res Cell Motil I998;19:575-602.

II. Gahlmann R, Troutt AB, Wade RP, et al. Alternative splicing generates variants in important functional domains of human slow skeletal troponin T. J Biol Chem I987;262:16122-6.

I2. Anderson PA, Greig A, Mark TM, et al. Molecular basis of human cardiac troponin $\mathrm{T}$ isoforms expressed in the developing, adult, and failing heart. Circ Res I995; 6:68I-6.

13. Filatov VL, Katrukha AG, Bulargina TV, et al. Troponin: structure, properties, and mechanism of functioning. Biochemistry (Mosc) 1999;64:969-85.

I4. Anderson PA, Malouf NN, Oakeley AE, et al. Troponin T isoform expression in humans. A comparison among normal and failing adult heart, fetal heart, and adult and fetal skeletal muscle. Circ Res 1991;69:1226-33.

I5. Muller-Bardorff M, Hallermayer K, Schroder A, et al. Improved troponin T ELISA specific for cardiac troponin T isoform: assay development and analytical and clinical validation. Clin Chem I997;43:458-66.

I6. Saggin L, Gorza L, Ausoni S, et al. Troponin I switching in the developing heart. $J$ Biol Chem 1989;264:16299-302.

I7. Toyota N, Shimada Y. Differentiation of troponin in cardiac and skeletal muscles in chicken embryos as studied by immunofluorescence microscopy. J Cell Biol I981;9I:497-504.

I8. Bodor GS, Porterfield D, Voss EM, et al. Cardiac troponin-I is not expressed in fetal and healthy or diseased adult human skeletal muscle tissue. Clin Chem I995;4I: I7I0-5.

I9. Bodor GS, Survant L, Voss EM, et al. Cardiac troponin T composition in normal and regenerating human skeletal muscle. Clin Chem 1997;43:476-84.

20. Katus HA, Looser S, Hallermayer K, et al. Development and in vitro characterization of a new immunoassay of cardiac troponin T. Clin Chem I992;38:386-93.

2I. Ricchiuti V, Voss EM, Ney A, et al. Cardiac troponin T isoforms expressed in renal diseased skeletal muscle will not cause false-positive results by the second generation cardiac troponin T assay by Boehringer Mannheim. Clin Chem I998;44:I9I9-24

22. Ricchiuti V, Apple FS. RNA expression of cardiac troponin T isoforms in diseased human skeletal muscle. Clin Chem 1999;45:2129-35.

23. Katus HA, Remppis A, Scheffold T, et al. Intracellular compartmentation of cardiac troponin $\mathrm{T}$ and its release kinetics in patients with reperfused and nonreperfused myocardial infarction. Am J Cardiol I991;67:1360-7.

24. Adams JE III, Schechtman KB, Landt Y, et al. Comparable detection of acute myocardial infarction by creatine kinase MB isoenzyme and cardiac troponin I. Clin Chem I994;40:129I-5.

25. Adams JE III, Bodor GS, Davila-Roman VG, et al. Cardiac troponin I. A marker with high specificity for cardiac injury. Circulation I993;88:I0I-6.

26. Katus HA, Remppis A, Neumann FJ, et al. Diagnostic efficiency of troponin T measurements in acute myocardial infarction. Circulation I991;83:902-I2.

27. Vatner SF, Baig H, Manders WT, et al. Effects of coronary artery reperfusion on myocardial infarct size calculated from creatine kinase. J Clin Invest 1978; 61:1048-56.
28. Tanaka H, Abe S, Yamashita T, et al. Serum levels of cardiac troponin I and troponin $\mathrm{T}$ in estimating myocardial infarct size soon after reperfusion. Coron Artery Dis I997;8:433-9.

29. Jaffe AS, Landt Y, Parvin CA, et al. Comparative sensitivity of cardiac troponin I and lactate dehydrogenase isoenzymes for diagnosing acute myocardial infarction. Clin Chem I996;42:1770-6.

30. Katus HA, Remppis A, Looser S, et al. Enzyme linked immuno assay of cardiac troponin $\mathrm{T}$ for the detection of acute myocardial infarction in patients. J Mol Cell Cardiol I989;2I:1349-53

3I. Ottani F, Galvani M, Nicolini FA, et al. Elevated cardiac troponin levels predict the risk of adverse outcome in patients with acute coronary syndromess. Am Heart 2000;140:917-27.

32. Luepker RV, Apple FS, Christenson RH, et al. Case definitions for acute coronary heart disease in epidemiology and clinical research studies: a statement from the AHA Council on Epidemiology and Prevention; AHA Statistics Committee; World Heart Federation Council on Epidemiology and Prevention; the European Society of Cardiology Working Group on Epidemiology and Prevention; Centers for Disease Control and Prevention; and the National Heart, Lung, and Blood Institute. Circulation 2003;108:2543-9.

33. Panteghini M, Pagani F, Yeo KT, et al. Evaluation of imprecision for cardiac troponin assays at low-range concentrations. Clin Chem 2004;50:327-32.

34. Apple FS. Clinical and analytical standardization issues confronting cardiac troponin I. Clin Chem 1999;45:18-20.

35. Ferrieres G, Calzolari C, Mani JC, et al. Human cardiac troponin I: precise identification of antigenic epitopes and prediction of secondary structure. Clin Chem I998;44:487-93.

36. Panteghini M, Gerhardt W, Apple FS, et al. Quality specifications for cardiac troponin assays. Clin Chem Lab Med 2001;39:175-9.

37. Tsung JS, Tsung SS. Creatine kinase isoenzymes in extracts of various human skeletal muscles. Clin Chem I986;32:1568-70.

38. Mair J. Cardiac troponin I and troponin T: are enzymes still relevant as cardiac markers? Clin Chim Acta 1997;257:99-II5.

39. Larca LJ, Coppola JT, Honig S. Creatine kinase MB isoenzyme in dermatomyositis: a noncardiac source. Ann Intern Med I98I;94:34I-3

40. Urdal P, Landaas S. Macro creatine kinase BB in serum, and some data on its prevalence. Clin Chem 1979;25:46I-5.

4I. Kohse KP, Wisser H. Antibodies as a source of analytical errors. J Clin Chem Clin Biochem I990;28:88I-92.

42. Mair J, Puschendorf B, Michel G. Clinical significance of cardiac contractile proteins for the diagnosis of myocardial injury. Adv Clin Chem 1994;31:63-98.

43. Adams JE III, Abendschein DR, Jaffe AS. Biochemical markers of myocardial injury. Is MB creatine kinase the choice for the I990s? Circulation 1993;88:750-63.

44. Adams JE III, Sicard GA, Allen BT, et al. Diagnosis of perioperative myocardial infarction with measurement of cardiac troponin I. N Engl J Med I994;330:670-4.

45. Adams JE III, Davila-Roman VG, Bessey PQ, et al. Improved detection of cardiac contusion with cardiac troponin I. Am Heart J I996;131:308-I2.

46. Jaffe A. Caveat emptor. Am J Med 2003;II5:24I-4.

47. Myocardial infarction redefined - a consensus document of the Joint European Society of Cardiology/American College of Cardiology Committee for the redefinition of myocardial infarction. Eur Heart J 2000;2I:I502-I3.

48. Alpert JS, Thygesen K, Antman E, et al. Myocardial infarction redefined - a consensus document of the Joint European Society of Cardiology/American College of Cardiology Committee for the redefinition of myocardial infarction. J Am Coll Cardiol 2000;36:959-69.

49. Lee TH, Rouan GW, Weisberg MC, et al. Sensitivity of routine clinical criteria for diagnosing myocardial infarction within 24 hours of hospitalization. Ann Intern Med I987;106:18I-6.

50. Jaffe AS, Ravkilde J, Roberts R, et al. It's time for a change to a troponin standard. Circulation 2000;102:1216-20.

5I. Wu AH, Apple FS, Gibler WB, et al. National Academy of Clinical Biochemistry Standards of Laboratory Practice: recommendations for the use of cardiac markers in coronary artery diseases. Clin Chem I999;45:1104-2I.

52. Fox KA, Birkhead J, Wilcox R, et al. British Cardiac Society Working Group on the definition of myocardial infarction. Heart 2004;90:603-9.

53. Wiviott SD, Cannon CP, Morrow DA, et al. Differential expression of cardiac biomarkers by gender in patients with unstable angina/non-ST-elevation myocardial infarction: a TACTICS-TIMI I8 (Treat Angina with Aggrastat and determine Cost of Therapy with an Invasive or Conservative Strategy-Thrombolysis In Myocardial Infarction I8) substudy. Circulation 2004;109:580-6.

54. Apple FS, Murakami MM. Serum 99th percentile reference cutoffs for seven cardiac troponin assays. Clin Chem 2004;50:1477-9.

55. Venge P, Johnston N, Lagerqvist B, et al. Clinical and analytical performance of the liaison cardiac troponin I assay in unstable coronary artery disease, and the impact of age on the definition of reference limits. A FRISC-II substudy. Clin Chem 2003;49:88o-6.

56. Christenson RH, Cervelli DR, Bauer RS, et al. Stratus(R) CS cardiac troponin I method: performance characteristics including imprecision at low concentrations. Clin Biochem 2004;37:679-83.

57. Apple FS, Wu AH, Jaffe AS. European Society of Cardiology and American College of Cardiology guidelines for redefinition of myocardial infarction: how to use existing assays clinically and for clinical trials. Am Heart J 2002;I44:98I-6.

58. Eggers KM, Oldgren J, Nordenskjold A, et al. Diagnostic value of serial measurement of cardiac markers in patients with chest pain: limited value of adding myoglobin to troponin I for exclusion of myocardial infarction. Am Heart J 2004;I48:574-8I. 
59. Zimmerman J, Fromm R, Meyer D, et al. Diagnostic marker cooperative study for the diagnosis of myocardial infarction. Circulation 1999;99:167I-7.

6o. Newby LK, Storrow AB, Gibler WB, et al. Bedside multimarker testing for risk stratification in chest pain units: The chest pain evaluation by creatine kinase-MB, myoglobin, and troponin I (CHECKMATE) study. Circulation 200I;I03:I832-7.

6r. Antman EM, Tanasijevic MJ, Thompson B, et al. Cardiac-specific troponin I levels to predict the risk of mortality in patients with acute coronary syndromes. $N$ Engl J Med I996;335:1342-9.

62. Hamm CW, Ravkilde J, Gerhardt W, et al. The prognostic value of serum troponin T in unstable angina. N Engl J Med I992;327:I46-50.

63. Lindahl B, Toss H, Siegbahn A, et al. Markers of myocardial damage and inflammation in relation to long-term mortality in unstable coronary artery disease. FRISC Study Group. Fragmin during Instability in Coronary Artery Disease. N Engl JMed 2000;343:II39-47.

64. Okamatsu K, Takano M, Sakai S, et al. Elevated troponin T levels and lesion characteristics in non-ST-elevation acute coronary syndromes. Circulation 2004;109:465-70.

65. Wong GC, Morrow DA, Murphy S, et al. Elevations in troponin T and I are associated with abnormal tissue level perfusion: a TACTICS-TIMI I8 substudy. Treat Angina with Aggrastat and Determine Cost of Therapy with an Invasive or Conservative Strategy-Thrombolysis in Myocardial Infarction. Circulation 2002;106:202-7.

66. Lindahl B, Venge P, Wallentin L. Troponin T identifies patients with unstable coronary artery disease who benefit from long-term antithrombotic protection. Fragmin in Unstable Coronary Artery Disease (FRISC) Study Group. J Am Coll Cardiol I997;29:43-8.

67. Morrow DA, Antman EM, Tanasijevic M, et al. Cardiac troponin I for stratification of early outcomes and the efficacy of enoxaparin in unstable angina: a TIMI-IIB substudy. J Am Coll Cardiol 2000;36:1812-7.

68. Hamm CW, Heeschen C, Goldmann B, et al. Benefit of abciximab in patients with refractory unstable angina in relation to serum troponin T levels. $c 7 \mathrm{E}_{3} \mathrm{Fab}$ Antiplatelet Therapy in Unstable Refractory Angina (CAPTURE) Study Investigators. N Engl J Med I999;340:I623-9.

69. Newby LK, Ohman EM, Christenson RH, et al. Benefit of glycoprotein IIb/IIIa inhibition in patients with acute coronary syndromes and troponin t-positive status: the paragon-B troponin T substudy. Circulation 200I;103:289I-6.

7o. Heeschen C, Hamm CW, Goldmann B, et al. Troponin concentrations for stratification of patients with acute coronary syndromes in relation to therapeutic efficacy of tirofiban. PRISM Study Investigators. Platelet Receptor Inhibition in Ischemic Syndrome Management. Lancet I999;354:1757-62.

7I. Fuchs S, Kornowski R, Mehran R, et al. Cardiac troponin I levels and clinical outcomes in patients with acute coronary syndromes: the potential role of early percutaneous revascularization. J Am Coll Cardiol I999;34:I704-Io.

72. Invasive compared with non-invasive treatment in unstable coronary-artery disease: FRISC II prospective randomised multicentre study. FRagmin and Fast Revascularisation during InStability in Coronary artery disease Investigators. Lancet 1999; 354:708-I5.

73. Cannon CP, Weintraub WS, Demopoulos LA, et al. Comparison of early invasive and conservative strategies in patients with unstable coronary syndromes treated with the glycoprotein IIb/IIIa inhibitor tirofiban. N Engl J Med 200I;344:I879-87.

74. Morrow DA, Cannon CP, Rifai N, et al. Ability of minor elevations of troponins and $\mathrm{T}$ to predict benefit from an early invasive strategy in patients with unstable angina and non-ST elevation myocardial infarction: results from a randomized trial. JAMA 2001;286:2405-I2.

75. Diderholm E, Andren B, Frostfeldt G, et al. The prognostic and therapeutic implications of increased troponin $\mathrm{T}$ levels and ST depression in unstable coronary artery disease: the FRISC II invasive troponin T electrocardiogram substudy. Am Heart $J_{2002}$; I43:760-7.

76. Yusuf S, Zhao F, Mehta SR, et al. Effects of clopidogrel in addition to aspirin in patients with acute coronary syndromes without ST-segment elevation. N Engl J Med 2001;345:494-502.

77. Ohman EM, Armstrong PW, Christenson RH, et al. Cardiac troponin T levels for risk stratification in acute myocardial ischemia. GUSTO IIA Investigators. $N$ EngIJ Med I996;335:I333-4I.

78. Newby LK, Christenson RH, Ohman EM, et al. Value of serial troponin T measures for early and late risk stratification in patients with acute coronary syndromes. The GUSTO-IIa Investigators. Circulation I998;98:1853-9.

79. Giannitsis E, Muller-Bardorff M, Lehrke S, et al. Admission troponin T level predicts clinical outcomes, TIMI flow, and myocardial tissue perfusion after primary percutaneous intervention for acute ST-segment elevation myocardial infarction. Circulation 2001;104:630-5.

8o. Luscher MS, Thygesen K, Ravkilde J, et al. Applicability of cardiac troponin T and I for early risk stratification in unstable coronary artery disease. TRIM Study Group. Thrombin Inhibition in Myocardial ischemia. Circulation 1997;96:2578-85.

8I. Christenson RH, Duh SH, Newby LK, et al. Cardiac troponin T and cardiac troponin I: relative values in short-term risk stratification of patients with acute coronary syndromes. GUSTO-IIa Investigators. Clin Chem I998;44:494-50I.

82. Wu AH, Ford L. Release of cardiac troponin in acute coronary syndromes: ischemia or necrosis? Clin Chim Acta 1999;284:I6I-74.

83. Ishikawa Y, Saffitz JE, Mealman TL, et al. Reversible myocardial ischemic injury is not associated with increased creatine kinase activity in plasma. Clin Chem I997; $43: 467-75$

84. Carlson RJ, Navone A, McConnell JP, et al. Effect of myocardial ischemia on cardiac troponin I and T. Am J Cardiol 2002;89:224-6.

85. Wu AH, Feng YJ, Moore R, et al. Characterization of cardiac troponin subunit release into serum after acute myocardial infarction and comparison of assays for troponin T and I. American Association for Clinical Chemistry Subcommittee on cTnI Standardization. Clin Chem I998;44:1198-208.

86. Katrukha AG, Bereznikova AV, Esakova TV, et al. Troponin I is released in bloodstream of patients with acute myocardial infarction not in free form but as complex. Clin Chem I997;43:1379-85.

87. Chen Y, Serfass RC, Mackey-Bojack SM, et al. Cardiac troponin T alterations in myocardium and serum of rats after stressful, prolonged intense exercise. $J$ App Physiol 2000;88:1749-55.

88. Feng YJ, Chen C, Fallon JT, et al. Comparison of cardiac troponin I, creatine kinase-MB, and myoglobin for detection of acute ischemic myocardial injury in a swine model. Am J Clin Pathol 1998;110:70-7.

89. Neumayr G, Gaenzer H, Pfister R, et al. Plasma levels of cardiac troponin I after prolonged strenuous endurance exercise. Am J Cardiol 2001;87:369-7I, Aro.

9o. Rifai N, Douglas PS, O'Toole M, et al. Cardiac troponin T and I, echocardiographic [correction of electrocardiographic] wall motion analyses, and ejection fractions in athletes participating in the Hawaii Ironman Triathlon. Am J Cardiol 1999;83: I085-9.

91. Muller-Bardorff M, Weidtmann B, Giannitsis E, et al. Release kinetics of cardiac troponin $\mathrm{T}$ in survivors of confirmed severe pulmonary embolism. Clin Chem 2002;48:673-5.

92. La Vecchia L, Ottani F, Favero L, et al. Increased cardiac troponin I on admission predicts in-hospital mortality in acute pulmonary embolism. Heart 2004;90:633-7.

93. Wu AH. Increased troponin in patients with sepsis and septic shock: myocardial necrosis or reversible myocardial depression? Intensive Care Med 200I;27:959-6I.

94. Goldstein JA. Right heart ischemia: pathophysiology, natural history, and clinical management. Prog Cardiovasc Dis 1998;40:325-4I.

95. Parker MM, Shelhamer JH, Bacharach SL, et al. Profound but reversible myocardial depression in patients with septic shock. Ann Intern Med I984;100:483-90.

96. Ellrodt AG, Riedinger MS, Kimchi A, et al. Left ventricular performance in septic shock: reversible segmental and global abnormalities. Am Heart J I985; II0:402-9.

97. Hamm CW, Goldmann BU, Heeschen C, et al. Emergency room triage of patients with acute chest pain by means of rapid testing for cardiac troponin T or troponin I. N Engl J Med I997;337:1648-53.

98. DeFilippi CR, Tocchi M, Parmar RJ, et al. Cardiac troponin T in chest pain unit patients without ischemic electrocardiographic changes: angiographic correlates and long-term clinical outcomes. J Am Coll Cardiol 2000;35:1827-34.

99. Apple FS, Murakami MM. Cardiac troponin and creatine kinase MB monitoring during in-hospital myocardial reinfarction. Clin Chem 2005;51(2):460-3. Epub 2004 Nov 24.

Ioo. Falahati A, Sharkey SW, Christensen D, et al. Implementation of serum cardiac troponin I as marker for detection of acute myocardial infarction. Am Heart J I999; I37:332-7.

IoI. Bodor GS, Porter S, Landt Y, et al. Development of monoclonal antibodies for an assay of cardiac troponin-I and preliminary results in suspected cases of myocardial infarction. Clin Chem I992;38:2203-I4.

I02. Licka M, Zimmermann R, Zehelein J, et al. Troponin T concentrations 72 hours after myocardial infarction as a serological estimate of infarct size. Heart 2002;87:520-4.

I03. Panteghini M, Cuccia C, Bonetti G, et al. Single-point cardiac troponin T at coronary care unit discharge after myocardial infarction correlates with infarct size and ejection fraction. Clin Chem 2002;48:I432-6.

I04. Ingkanisorn WP, Rhoads KL, Aletras AH, et al. Gadolinium delayed enhancement cardiovascular magnetic resonance correlates with clinical measures of myocardial infarction. J Am Coll Cardiol 2004;43:2253-9.

I05. Fuchs S, Stabile E, Mintz GS, et al. Intravascular ultrasound findings in patients with acute coronary syndromes with and without elevated troponin I level. Am J Cardiol 2002;89:IIII-3.

Io6. Herrmann J, Haude M, Lerman A, et al. Abnormal coronary flow velocity reserve after coronary intervention is associated with cardiac marker elevation. Circulation 200I;I03:2339-45.

I07. Williams DO. A twist in our understanding of enzyme elevation after coronary intervention. J Am Coll Cardiol 2003;42:1906-8.

I08. Iakovou I, Mintz GS, Dangas G, et al. Increased CK-MB release is a "trade-off" for optimal stent implantation: an intravascular ultrasound study. J Am Coll Cardiol 2003;42:1900-5.

Io9. Jaffe AS, Ritter C, Meltzer V, et al. Unmasking artifactual increases in creatine kinase isoenzymes in patients with renal failure. J Lab Clin Med I984;104:193-202.

IIo. Robbins MJ, Epstein EM, Shah S. Creatine kinase subform analysis in hemodialysis patients without acute coronary syndromes. Nephron 1997;76:296-9.

III. Miller WL, Garratt KN, Burritt MF, et al. Timing of peak troponin T and creatine kinase-MB elevations after percutaneous coronary intervention. Chest 2004;125: 275-80.

II2. Landesberg G, Shatz V, Akopnik I, et al. Association of cardiac troponin, CK-MB, and postoperative myocardial ischemia with long-term survival after major vascular surgery. J Am Coll Cardiol 2003;42:1547-54.

II3. Pasceri V, Patti G, Nusca A, et al; ARMYDA Investigators. Randomized trial of atorvastatin for reduction of myocardial damage during coronary intervention: results from the ARMYDA (Atorvastatin for Reduction of MYocardial Damage during Angioplasty) study. Circulation 2004; IIO(6):674-8. Epub 2004 Jul 26.

II4. Adams JE III. The use of biomarkers to provide diagnostic and prognostic information following cardiac surgery. In: Wu AHB, editor. Cardiac markers. 2nd ed. Totowa (NJ): Humana Press Inc.; 2003. p. III-2I.

II5. Bonnefoy E, Filley S, Kirkorian G, et al. Troponin I, troponin T, or creatine kinase$\mathrm{MB}$ to detect perioperative myocardial damage after coronary artery bypass surgery. Chest 1998;114:482-6. 
II6. Carrier M, Pellerin M, Perrault LP, et al. Troponin levels in patients with myocardial infarction after coronary artery bypass grafting. Ann Thorac Surg 2000;69: 435-40.

II7. Greenson N, Macoviak J, Krishnaswamy P, et al. Usefulness of cardiac troponin I in patients undergoing open heart surgery. Am Heart J 200I;I4I:447-55.

II8. Lehrke S, Steen H, Sievers $\mathrm{HH}$, et al. Cardiac troponin T for prediction of shortand long-term morbidity and mortality after elective open heart surgery. Clin Chem 2004;50:1560-7.

IIg. Thielmann M, Massoudy P, Marggraf G, et al. Role of troponin I, myoglobin, and creatine kinase for the detection of early graft failure following coronary artery bypass grafting. Eur J Cardiothorac Surg 2004;26:102-9.

I20. Pelletier LC, Carrier M, Leclerc Y, et al. Intermittent antegrade warm versus cold blood cardioplegia: a prospective, randomized study. Ann Thorac Surg 1994;58:4I8. [discussion 48-9]

I2I. Chocron S, Etievent JP. Cardiac troponin I plasma levels for diagnosis and quantitation of perioperative myocardial damage in patients undergoing coronary artery bypass surgery. Eur J Cardiothorac Surg I998;13:718-20.

I22. Khan NE, De Souza A, Mister R, et al. A randomized comparison of off-pump and on-pump multivessel coronary-artery bypass surgery. N Engl J Med 2004;350:2I-8.

123. Selvanayagam JB, Petersen SE, Francis JM, et al. Effects of off-pump versus onpump coronary surgery on reversible and irreversible myocardial injury: a randomized trial using cardiovascular magnetic resonance imaging and biochemical markers. Circulation 2004;109:345-50.

I24. McCullough PA, Nowak RM, Foreback C, et al. Performance of multiple cardiac biomarkers measured in the emergency department in patients with chronic kidney disease and chest pain. Acad Emerg Med 2002;9:1389-96.

I25. McLaurin MD, Apple FS, Falahati A, et al. Cardiac troponin I and creatine kinaseMB mass to rule out myocardial injury in hospitalized patients with renal insufficiency. Am J Cardiol I998;82:973-5

126. Aviles RJ, Askari AT, Lindahl B, et al. Troponin T levels in patients with acute coronary syndromes, with or without renal dysfunction. N Engl JMed 2002;346:2047-52.

127. Freda BJ, Tang WH, Van Lente F, et al. Cardiac troponins in renal insufficiency: review and clinical implications. J Am Coll Cardiol 2002;40:2065-71.

I28. De Zoysa JR. Cardiac troponins and renal disease. Nephrology 2004;9:83-8.

I29. Iliou MC, Fumeron C, Benoit MO, et al. Factors associated with increased serum levels of cardiac troponins T and I in chronic haemodialysis patients: Chronic Haemodialysis And New Cardiac Markers Evaluation (CHANCE) study. Nephrol Dial Transplant 200I;16:1452-8.

I30. Ooi DS, Veinot JP, Wells GA, et al. Increased mortality in hemodialyzed patients with elevated serum troponin T: a one-year outcome study. Clin Biochem I999;32: 647-52.

I3I. Stolear JC, Georges B, Shita A, et al. The predictive value of cardiac troponin T measurements in subjects on regular haemodialysis. Nephrol Dial Transplant I999;I4:I96I-7.

132. Ooi DS, House AA. Cardiac troponin T in hemodialyzed patients. Clin Chem I998;44:1410-6

I33. Goicoechea M, Garca de Vinuesa S, Gomez-Campdera F, et al. Clinical significance of cardiac troponin $\mathrm{T}$ levels in chronic kidney disease patients: predictive value for cardiovascular risk. Am J Kidney Dis 2004;43:846-53.

I34. Mallamaci F, Zoccali C, Parlongo S, et al. Diagnostic value of troponin T for alterations in left ventricular mass and function in dialysis patients. Kidney Int 2002; 62:1884-90

I35. Jung HH, Ma KR, Han H. Elevated concentrations of cardiac troponins are associated with severe coronary artery calcification in asymptomatic haemodialysis patients. Nephrol Dial Transplant 2004;19(12):3117-23. Epub 2004 Nov I6.

I36. Lowbeer C, Ottosson-Seeberger A, Gustafsson SA, et al. Increased cardiac troponin $\mathrm{T}$ and endothelin-I concentrations in dialysis patients may indicate heart disease. Nephrol Dial Transplant I999; I4:I948-55.

137. Tun A, Khan IA, Win MT, et al. Specificity of cardiac troponin I and creatine kinase-MB isoenzyme in asymptomatic long-term hemodialysis patients and effect of hemodialysis on these cardiac markers. Cardiology 1998;90:280-5.

I38. Ooi DS, Isotalo PA, Veinot JP. Correlation of antemortem serum creatine kinase, creatine kinase-MB, troponin I, and troponin T with cardiac pathology. Clin Chem 2000;46:338-44.

139. Apple FS, Murakami MM, Pearce LA, et al. Predictive value of cardiac troponin I and T for subsequent death in end-stage renal disease. Circulation 2002;106:294I-5

I40. deFilippi C, Wasserman S, Rosanio S, et al. Cardiac troponin T and C-reactive protein for predicting prognosis, coronary atherosclerosis, and cardiomyopathy in patients undergoing long-term hemodialysis. JAMA 2003;290:353-9.

I4I. Apple FS, Murakami MM, Pearce LA, et al. Multi-biomarker risk stratification of Nterminal pro-B-type natriuretic peptide, high-sensitivity $\mathrm{C}$-reactive protein, and cardiac troponin T and I in end-stage renal disease for all-cause death. Clin Chem 2004;50(I2):2279-85. Epub 2004 Sep I3.

142. Nakamura T, Ushiyama C, Osada S, et al. Effect of dilazep dihydrochloride on serum cardiac troponin T levels in hemodialysis patients. Kidney Blood Press Res 2002;25:50-4.

I43. Porter GA, Norton TL, Lindsley J, et al. Relationship between elevated serum troponin values in end-stage renal disease patients and abnormal isotopic cardiac scans following stress. Ren Fail 2003;25:55-65.

144. Wayand D, Baum H, Schatzle G, et al. Cardiac troponin T and I in end-stage rena failure. Clin Chem 2000;46:1345-50.

I45. Thambyrajah J, Landray MJ, McGlynn FJ, et al. Abnormalities of endothelial function in patients with predialysis renal failure. Heart 2000;83:205-9.

I46. Scott B, Deman A, Peeters P, et al. Cardiac troponin T and malondialdehyde modi- fied plasma lipids in haemodialysis patients. Nephrol Dial Transplant 2003;18: 737-42.

147. Hung SY, Hung YM, Fang HC, et al. Cardiac troponin I and creatine kinase isoenzyme MB in patients with intradialytic hypotension. Blood Purif 2004;22:338-43.

I48. Khan IA, Wattanasuwan N, Mehta NJ, et al. Prognostic value of serum cardiac troponin I in ambulatory patients with chronic renal failure undergoing long-term hemodialysis: a two-year outcome analysis. J Am Coll Cardiol 200I;38:99I-8.

I49. Ziebig R, Lun A, Hocher B, et al. Renal elimination of troponin T and troponin I. Clin Chem 2003;49:II9I-3.

I50. Guest TM, Ramanathan AV, Tuteur PG, et al. Myocardial injury in critically ill patients. A frequently unrecognized complication. JAMA 1995;273:1945-9.

I5I. Wright RS, Williams BA, Cramner H, et al. Elevations of cardiac troponin I are associated with increased short-term mortality in noncardiac critically ill emergency department patients. Am J Cardiol 2002;90:634-6.

152. Mair P, Mair J, Koller J, et al. Cardiac troponin T in the diagnosis of heart contusion. Lancet I99I;338:693.

I53. Salim A, Velmahos GC, Jindal A, et al. Clinically significant blunt cardiac trauma: role of serum troponin levels combined with electrocardiographic findings. Trauma 200I;50:237-43.

154. Bertinchant JP, Polge A, Mohty D, et al. Evaluation of incidence, clinical significance, and prognostic value of circulating cardiac troponin I and T elevation in hemodynamically stable patients with suspected myocardial contusion after blunt chest trauma. J Trauma 2000;48:924-3I.

I55. Lund M, French JK, Johnson RN, et al. Serum troponins T and I after elective cardioversion. Eur Heart J 2000;2I:245-53.

I56. Rao AC, Naeem N, John C, et al. Direct current cardioversion does not cause cardiac damage: evidence from cardiac troponin T estimation. Heart I998;80:229-30.

I57. Allan JJ, Feld RD, Russell AA, et al. Cardiac troponin I levels are normal or minimally elevated after transthoracic cardioversion. J Am Coll Cardiol 1997;30:1052-6.

158. Bonnefoy E, Chevalier P, Kirkorian G, et al. Cardiac troponin I does not increase after cardioversion. Chest I997;III:I5-8.

I59. Mullner M, Hirschl MM, Herkner H, et al. Creatine kinase-MB fraction and cardiac troponin $\mathrm{T}$ to diagnose acute myocardial infarction after cardiopulmonary resuscitation. J Am Coll Cardiol I996;28:1220-5.

I6o. Grubb NR, Fox KA, Cawood P. Resuscitation from out-of-hospital cardiac arrest: implications for cardiac enzyme estimation. Resuscitation 1996;33:35-4I.

I6I. Katritsis D, Hossein-Nia M, Anastasakis A, et al. Use of troponin-T concentration and kinase isoforms for quantitation of myocardial injury induced by radiofrequency catheter ablation. Eur Heart J I997; I8:1007-I3.

I62. Manolis AS, Vassilikos V, Maounis T, et al. Detection of myocardial injury during radiofrequency catheter ablation by measuring serum cardiac troponin I levels: procedural correlates. J Am Coll Cardiol 1999;34:1099-105.

I63. Ammann P, Maggiorini M, Bertel O, et al. Troponin as a risk factor for mortality in critically ill patients without acute coronary syndromes. J Am Coll Cardiol 2003;4I: 2004-9.

I64. ver Elst KM, Spapen HD, Nguyen DN, Garbar C, Huyghens LP, Gorus FK. Cardiac troponins I and T are biological markers of left ventricular dysfunction in septic shock. Clin Chem 2000;46:650-7.

I65. Morrow D. Cardiac-specific troponins beyond ischemic heart disease. In: Wu AHB, editor. Cardiac markers. 2nd ed. Totowa (NJ): Humana Press Inc., 2003. p. I49-70.

I66. Thiru Y, Pathan N, Bignall S, et al. A myocardial cytotoxic process is involved in the cardiac dysfunction of meningococcal septic shock. Crit Care Med 2000;28:297983.

I67. Spies C, Haude V, Fitzner R, et al. Serum cardiac troponin T as a prognostic marker in early sepsis. Chest 1998 ; II 3 :I055-63.

I68. Kollef MH, Ladenson JH, Eisenberg PR. Clinically recognized cardiac dysfunction: an independent determinant of mortality among critically ill patients. Is there a role for serial measurement of cardiac troponin I? Chest I997; III:I340-7.

I69. Cardinale D, Sandri MT, Colombo A, et al. Prognostic value of troponin I in cardiac risk stratification of cancer patients undergoing high-dose chemotherapy. Circulation 2004; I09:2749-54.

I70. Stelow EB, Johari VP, Smith SA, et al. Propofol-associated rhabdomyolysis with cardiac involvement in adults: chemical and anatomic findings. Clin Chem 2000;46:577-8I

I7I. Punukollu G, Gowda RM, Khan IA, et al. Elevated serum cardiac troponin I in rhabdomyolysis. Int J Cardiol 2004;96:35-40.

172. Jaffe A. Use of cardiac biomarkers for detection of myocarditis. In: Cooper LT, editor. Myocarditis: from bench to bedside. Totowa (NJ): Humana Press Inc.; 2002. p. $283-94$.

173. Smith SC, Ladenson JH, Mason JW, et al. Elevations of cardiac troponin I associated with myocarditis. Experimental and clinical correlates. Circulation 1997;95: I63-8.

174. Lauer B, Niederau C, Kuhl U, et al. Cardiac troponin $\mathrm{T}$ in patients with clinically suspected myocarditis. J Am Coll Cardiol 1997;30:1354-9.

175. Bonnefoy E, Godon P, Kirkorian G, et al. Serum cardiac troponin I and STsegment elevation in patients with acute pericarditis. Eur Heart J 2000;2I:832-6.

176. Brandt RR, Filzmaier K, Hanrath P. Circulating cardiac troponin I in acute pericarditis. Am J Cardiol 200I;87:1326-8.

I77. Miller WL, Wright RS, McGregor CG, et al. Troponin levels in patients with amyloid cardiomyopathy undergoing cardiac transplantation. Am J Cardiol 2001;88: $8 \mathrm{I} 3-5$.

178. Dispenzieri A, Kyle RA, Gertz MA, et al. Survival in patients with primary systemic amyloidosis and raised serum cardiac troponins. Lancet 2003;36r:1787-9. 
179. Dispenzieri A, Gertz MA, Kyle RA, et al. Prognostication of survival using cardiac troponins and $\mathrm{N}$-terminal pro-brain natriuretic peptide in patients with primary systemic amyloidosis undergoing peripheral blood stem cell transplantation. Blood 2004; I04:I88I-7.

I8o. Dispenzieri A, Gertz MA, Kyle RA, et al. Serum cardiac troponins and N-terminal pro-brain natriuretic peptide: a staging system for primary systemic amyloidosis. $J$ Clin Oncol 2004;22:375I-7.

I8I. Feng J, Schaus BJ, Fallavollita JA, et al. Preload induces troponin I degradation independently of myocardial ischemia. Circulation 2001;103:2035-7.

I82. Roongsritong C, Warraich I, Bradley C. Common causes of troponin elevations in the absence of acute myocardial infarction: incidence and clinical significance. Chest 2004;125:1877-84

183. Coma-Canella I, Gamallo C, Martinez Onsurbe P, et al. Acute right ventricular infarction secondary to massive pulmonary embolism. Eur Heart J I988;9:534-40.

184. Pruszczyk P, Szulc M, Horszczaruk G, et al. Right ventricular infarction in a patient with acute pulmonary embolism and normal coronary arteries. Arch Intern Med 2003;I63:IIIO-I.

I85. Giannitsis E, Muller-Bardorff $M$, Kurowski V, et al. Independent prognostic value of cardiac troponin $\mathrm{T}$ in patients with confirmed pulmonary embolism. Circulation 2000;102:21I-7.

I86. Mehta NJ, Jani K, Khan IA. Clinical usefulness and prognostic value of elevated cardiac troponin I levels in acute pulmonary embolism. Am Heart J 2003;I45:82I-5.

I87. Konstantinides S, Geibel A, Olschewski M, et al. Importance of cardiac troponins I and $\mathrm{T}$ in risk stratification of patients with acute pulmonary embolism. Circulation 2002;106:1263-8.

188. Meyer T, Binder L, Hruska N, et al. Cardiac troponin I elevation in acute pulmonary embolism is associated with right ventricular dysfunction. J Am Coll Cardiol 2000;36:1632-6.
I89. Kucher N, Goldhaber SZ. Cardiac biomarkers for risk stratification of patients with acute pulmonary embolism. Circulation 2003;108:219I-4.

I9o. Torbicki A, Kurzyna M, Kuca P, et al. Detectable serum cardiac troponin T as a marker of poor prognosis among patients with chronic precapillary pulmonary hypertension. Circulation 2003;108:844-8.

I9I. Missov E, Calzolari C, Pau B. Circulating cardiac troponin I in severe congestive heart failure. Circulation 1997;96:2953-8.

I92. Horwich TB, Patel J, MacLellan WR, et al. Cardiac troponin I is associated with impaired hemodynamics, progressive left ventricular dysfunction, and increased mortality rates in advanced heart failure. Circulation 2003;108:833-8.

193. Perna ER, Macin SM, Canella JPC, et al. Ongoing myocardial injury in stable severe heart failure: value of cardiac troponin T monitoring for high-risk patient identification. Circulation 2004;110:2376-82.

I94. Sato Y, Yamada T, Taniguchi R, et al. Persistently increased serum concentrations of cardiac troponin $\mathrm{t}$ in patients with idiopathic dilated cardiomyopathy are predictive of adverse outcomes. Circulation 2001;103:369-74.

I95. Hamwi SM, Sharma AK, Weissman NJ, et al. Troponin-I elevation in patients with increased left ventricular mass. Am J Cardiol 2003;92:88-9o.

I96. Bugiardini R, Bairey Merz CN. Angina with "normal" coronary arteries: a changing philosophy. JAMA 2005;293:477-84.

197. Kricka LJ. Human anti-animal antibody interferences in immunological assays Clin Chem 1999;45:942-56.

Correspondence to: Dr. Allan S. Jaffe, Cardiovascular Division, Gonda 5, Mayo Clinic, 200 First St. SW, Rochester MN 55905, USA; jaffe.allan@mayo.edu

\section{Canadian Medical Association}

\section{Special Awards - Call for Nominations}

The Canadian Medical Association invites nominations for the 2006 special awards.

- Medal of Honour

- F.N.G. Starr Award

- Medal of Service

- May Cohen Award for Women Mentors

- Sir Charles Tupper Award for Political Action

- Award for Excellence in Health Promotion

- CMA Award for Young Leaders

Refer to the "Awards from CMA" section on cma.ca for detailed criteria on each of the awards or contact the awards co-ordinator at $800663-7336 \times 2280$.

Nominations should be submitted to:

Chair, Committee on Archives and Awards c/o Committee Co-ordinator

Strategic and Corporate Affairs

Canadian Medical Association

1867 Alta Vista Dr.

Ottawa ON K1G 3 Y6

Closing date for receipt of nominations is Nov. 30, 2005.

\section{Association médicale canadienne}

\author{
Prix spéciaux pour l'an 2006 - Appel de candidatures
}

L'Association médicale canadienne sollicite des candidatures à ses prix spéciaux pour l'an 2006.

- Médaille d'honneur

- Prix F.N.G. Starr

- Médaille de service

- Prix May-Cohen pour femmes mentors

- Prix Sir-Charles-Tupper d'action politique

- Prix d'excellence de l'AMC en promotion de la santé

- Prix des jeunes chefs de file de l'AMC

Voir «Prix et distinctions de l'AMC» sur le site amc.ca pour les critères détaillés de chaque prix ou contacter la coordonnatrice des prix au $800663-7336$, poste 2280 .

Les candidatures doivent être soumises au :

Présidente, Comité des archives et des distinctions a/s Coordonnatrice des comités

Affaires générale et Stratégiques

Association médicale canadienne

1867, promenade Alta Vista

Ottawa (Ontario) K1G 3 Y6

Les candidatures doivent être présentées au plus tard le 30 novembre 2005 .

\section{ASSOCIATION
MÉDICALE
MEDICAL \\ CANADIENNE \& ASSOCIATION}

